\title{
Review \\ Specific residue: application of orthogonal contrasts when heteroscedasticity is present
}

\author{
Maria Cristina Stolf Nogueira \\ USP/ESALQ - Depto. de Ciências Exatas, C.P.9 - 13418-900 - Piracicaba, SP - Brasil - e-mail \\ $<m c s n o g u e @ e s a l q . u s p . b r>$.
}

\begin{abstract}
When experimental data are submitted to analysis of variance, the assumption of data homoscedasticity (variance homogeneity among treatments), associated to the adopted mathematical model must be satisfied. This verification is necessary to ensure the correct test for the analysis. In some cases, when data homoscedascity is not observed, errors may invalidate the analysis. An alternative to overcome this difficulty is the application of the specific residue analysis, which consists of the decomposition of the residual sum of squares in its components, in order to adequately test the correspondent orthogonal contrasts of interest between treatment means. Although the decomposition of the residual sum of squares is a seldom used procedure, it is useful for a better understanding of the residual mean square nature and to validate the tests to be applied. The objective of this review is to illustrate the specific residue application as a valid and adequate alternative to analyze data from experiments following completely randomized and randomized complete block designs in the presence of heteroscedasticity.

Key words: analysis of variance, completely randomized design, randomized complete block design
\end{abstract}

\section{Resíduo específico: aplicação de contrastes ortogonais na presença da heterocedasticidade}

\begin{abstract}
RESUMO: Ao realizar-se a análise da variância de um conjunto de dados, pressupõe-se que o critério de homocedasticidade (homogeneidade de variâncias entre tratamentos), associada ao modelo matemático adotado, seja satisfeito. Esta verificação se faz necessária para a correta aplicação dos testes de significância. Quando não é satisfeita, em certos casos, compromete a normalidade dos erros. Uma alternativa para contornar essa deficiência é a aplicação do resíduo específico, que consiste em decompor a soma de quadrados do resíduo em componentes, correspondentes aos contrastes ortogonais de interesse, apropriados para testar cada contraste ortogonal entre médias de tratamentos. A decomposição da soma de quadrados do resíduo é um procedimento pouco utilizado, mas é útil para melhor compreensão da natureza do quadrado médio residual e garantir a validade dos testes aplicados. Nessa revisão avaliou-se a aplicação dos resíduos específicos como alternativa válida e adequada, na análise de dados obtidos de experimentos que seguem a estrutura dos delineamentos inteiramente casualizados e em blocos casualizados, na presença da heterocedasticidade.

Palavras-chave: análise da variância, delineamento inteiramente casualizado, delineamento em blocos casualizados
\end{abstract}

\section{Introduction}

The analysis of variance of experimental data requires that the assumption of homoscedasticity (similar variances among treatments), associated to the adopted mathematical model is satisfied. This verification is necessary for a correct significance of the test application. When this condition is not met the heteroscedasticity is prevailing (variance heterogeneity).

The heteroscedasticity can be classified as regular and irregular according to Steel and Torrie (1981) based on Cochran (1947). The regular type is generally originated from data non-normality and some type of relationship between means and variance treatments. In this case, the data may be transformed to have variance stability among treatments and, as a consequence, the errors will fit into an approximately normal distribution. The irregular type is characterized by certain treatments showing significantly higher variability compared to others, not necessarily presenting a relation between means and variances. In this case, Cochran and Cox (1957, 1971) recommended that such high variability treatments are omitted or that treatments are subdivided into homocedasticity groups in such way that they may present similar variances; or yet, to subdivide the residual sum of squares (SSResidual) in applicable components for the several comparisons of interest, thus obtaining specific residues.

When an analysis of variance is performed, the sum of squares of the treatments (SSTreatment) can be decomposed into components corresponding to orthogonal contrasts; in the same way, the residual sum of squares (SSResidual) can also be decomposed into their orthogonal contrast components, giving origin to the specific residues that are appropriate to test each contrast between treatment means. 
The residual sum of squares (SSResidual) decomposition is not a usual procedure as the treatment sum of squares (SSTreatment) decomposition, but according to Cochran and Cox $(1957,1971)$, it can be applied when there are reasons suggesting the presence of irregular types of heteroscedasticity. In this case, the SSResidual decomposition is useful to better understand the residual mean square (MSResidual) nature and validate the tests to be applied.

A residual sum of squares (SSResidual) decomposition for experimental data of a randomized complete block design was presented by Steel and\& Torrie (1981); initially, they established an orthogonal contrast grouping for treatments and thereafter they obtained the value of each contrast for each block. The authors concluded that if the randomized complete block design is valid, any comparison within each block is not influenced by the general level of the block. As a consequence, the variance for any comparison within blocks is appropriate to test contrasts between treatment means. The procedure was numerically shown.

In presence of the heteroscedasticity among experiments, when a group of experiments is considered, the interaction effects involving experiments (assumed as randomized effects) are influenced. An appropriate alternative to analyze the experimental data is the application of the specific residue method. With the objective to illustrate this case, Oliveira and Nogueira (2007) applied the specific residue method on sugarcane yield $\left(\mathrm{t} \mathrm{ha}{ }^{-1}\right)$ experimental data obtained from a group of eleven experiments characterized by the presence of heteroscedasticity among experiments. Each experiment had a randomized incomplete block design, arranged in a $3^{3}$ NPK factorial $(27$ treatments $=$ three blocks $\times$ nine experimental units). The confounding of two degrees of freedom corresponding to the block effects plus NPK interaction effects was considered. No replication was applied to blocks.

The objective of this review is to illustrate the application of specific residues as an alternative procedure to analyze data showing heteroscedasticity among treatments.

\section{Material and Methods}

The methods, definitions and concepts on orthogonal contrasts applied to obtain specific residues can be found in Nogueira (2004). To bypassthe irregular heteroscedasticity present in the experimental data of a randomized complete block design, Ferreira (1978) presenteda mathematical procedure to obtain the specific residue sum of squares, correspondent to the appropriate components for comparisons (orthogonal contrasts) of interest, using the orthogonal transformation method. Thus, the specific residue sum of squares of the $\mathrm{Y}_{\mathrm{h}}$ component $\left(\operatorname{SSR}\left(\mathrm{Y}_{\mathrm{h}}\right)\right)$ is given by

$\operatorname{SSR}\left(\mathrm{Y}_{\mathrm{h}}\right)=\frac{1}{\sum_{\mathrm{i}=1}^{\mathrm{I}} \mathrm{c}_{\mathrm{hi}}^{2}}\left[\sum_{\mathrm{j}=1}^{\mathrm{J}} \hat{\mathrm{Y}}_{\mathrm{hj}}^{2}-\frac{\hat{\mathrm{Y}}_{\mathrm{h}}^{2}}{\mathrm{~J}}\right]$, with (J-1) degrees of freedom and $\hat{Y}_{\mathrm{hj}}$ is the $\mathrm{Y}_{\mathrm{hj}}$ contrast estimate, correspondent to the $\mathrm{Y}_{h}$ contrast application within block $\mathrm{j}$, for $\mathrm{j}=1, \ldots, \mathrm{J}$,

$$
\begin{aligned}
& \hat{\mathrm{Y}}_{\mathrm{hj}}=\sum_{\mathrm{i}=1}^{\mathrm{I}} \mathrm{c}_{\mathrm{hi}} \mathrm{y}_{\mathrm{ij}} \text {, such that } \sum_{\mathrm{i}=1}^{\mathrm{I}} \mathrm{c}_{\mathrm{hi}}=0 \text { and } \\
& \hat{\mathrm{Y}}_{\mathrm{h}}=\sum_{\mathrm{j}=1}^{J} \hat{\mathrm{Y}}_{\mathrm{hj}}=\sum_{i=1}^{I} c_{h i} \bar{y}_{i}=\frac{1}{J} \sum_{\mathrm{i}=1}^{\mathrm{I}} c_{h i} \mathrm{y}_{\mathrm{i} .}
\end{aligned}
$$

where $I$ is the total number of treatments, for $\mathrm{i}=1$, ..., I; $\mathrm{c}_{\mathrm{hi}}$ is the associated coefficient of the i-esimal treatment mean in the h-esimal contrast; $\hat{\mathrm{Y}}_{\mathrm{h}}$ is the $\mathrm{h}$ esimal contrast estimate, for $\mathrm{h}=1, \ldots,(\mathrm{I}-1) ; \mathrm{y}_{\mathrm{ij}}$ is the observed value to $\mathrm{i}$-esimal treatment in j-esimal block; $y_{i .}=\sum_{j=1}^{J} y_{i j}$ the total sum of the i-esimal treatment and $\bar{y}_{i}=\frac{y_{i .}}{J}$ the mean of the i-esimal treatment. Two contrasts are orthogonal when $\sum_{\mathrm{i}=1}^{\mathrm{I}} \mathrm{c}_{\mathrm{hi}} \mathrm{c}_{\mathrm{h}^{\prime} \mathrm{i}}=0$, for $\mathrm{h} \neq \mathrm{h} \mathrm{h}^{\prime}=1, \ldots$,
(I-1).

$\sum_{\mathrm{h}=1}^{\mathrm{I}-1} \operatorname{SSR}\left(\mathrm{Y}_{\mathrm{h}}\right)=$ SSResidual has (I-1) (J-1) degrees of free$\mathrm{d}_{\mathrm{I}} \mathrm{m}$ and the residual mean square for $\mathrm{Y}_{\mathrm{h}}, \operatorname{MSR}\left(\mathrm{Y}_{\mathrm{h}}\right)=$ $\frac{1}{\mathrm{~J}-1} \operatorname{SSR}\left(\mathrm{Y}_{\mathrm{h}}\right)$ has $(\mathrm{J}-1)$ degrees of freedom.

Thus, the hypothesis $\mathrm{H}_{0}: \mathrm{Y}_{h}=0$ vs. $\mathrm{H}_{\mathrm{a}}: \mathrm{Y}_{\mathrm{h}} \neq 0$, for $\mathrm{h}=1, \ldots,(\mathrm{I}-1)$, is tested by the application of the $\mathrm{F}$ test, and $F_{h}=\frac{\operatorname{MS}\left(Y_{h}\right)}{\operatorname{MSR}\left(Y_{h}\right)} \sim F_{(1,(J-1))}$. where $\operatorname{MS}\left(Y_{h}\right)$ is the mean square referred to the $\mathrm{Y}_{\mathrm{h}}$ component, with one degree of freedom, obtained as follows:

$$
\begin{aligned}
& \operatorname{MS}\left(Y_{h}\right)=\frac{\operatorname{SS}\left(Y_{h}\right)}{1} \text { and } \\
& \operatorname{SS}\left(Y_{h}\right)=\frac{J \hat{Y}_{h}^{2}}{\sum_{i=1}^{I} c_{h i}^{2}}=\frac{J\left(\sum_{i=1}^{I} c_{h i} \bar{y}_{i .}\right)^{2}}{\sum_{i=1}^{I} c_{h i}^{2}}=\frac{J\left(\sum_{i=1}^{I} c_{h i} \frac{y_{i .}}{J}\right)^{2}}{\sum_{i=1}^{I} c_{h i}^{2}}=\frac{\left(\sum_{i=1}^{I} c_{h i} y_{i .}\right)^{2}}{J \sum_{i=1}^{I} c_{h i}^{2}}
\end{aligned}
$$

In the case of a completely randomized design experiment in presence of irregular heteroscedascity SSResidual is decomposed in specific residues as shown by Nogueira (1984) and Nogueira and Campos (1985). These authors developed the decomposition of SSResidual and presented appropriate specific residues to test each contrast, and also identified how the specific residue sum of squares refers to the $\mathrm{Y}_{h}$ component $\left(\operatorname{SSR}\left(\mathrm{Y}_{\mathrm{h}}\right)\right)$. The development of the specific residue sum of squares in relationto the $\mathrm{Y}_{h}$ component was obtained by applying the mathematical expectance $(\mathrm{E})$ on $\operatorname{SSR}\left(\mathrm{Y}_{\mathrm{h}}\right)$ of the randomized complete block design experiment, as follows:

$\mathrm{E}\left[\operatorname{SSR}\left(\mathrm{Y}_{\mathrm{h}}\right)\right]=\mathrm{E}\left[\frac{1}{\sum_{\mathrm{i}=1}^{\mathrm{I}} \mathrm{c}_{\mathrm{hi}}^{2}}\left[\sum_{\mathrm{j}=1}^{\mathrm{J}} \hat{\mathrm{Y}}_{\mathrm{hj}}^{2}-\frac{\hat{\mathrm{Y}}_{\mathrm{h}}^{2}}{\mathrm{~J}}\right]\right]$,

assuming that $\mathrm{E}\left(\mathrm{t}_{\mathrm{i}}\right)=\mathrm{t}_{\mathrm{i}}, \mathrm{E}\left(\mathrm{t}_{\mathrm{i}}^{2}\right)=\mathrm{t}_{\mathrm{i}}^{2}, \mathrm{E}\left(\mathrm{e}_{\mathrm{ij}}\right)=0$ and $\mathrm{E}\left(\mathrm{e}_{\mathrm{ij}}^{2}\right)$ $=\sigma_{i}^{2}$; where $t_{i}$ is the i-esimal treatment effect, $e_{i j}$ is the experimental error associated to $\mathrm{y}_{\mathrm{iji}}$. The specific residue sum of squares for $\mathrm{Y}_{\mathrm{h}}\left(\operatorname{SSR}\left(\mathrm{Y}_{\mathrm{h}}\right)\right)$ obtained is presented as follows: 
$\operatorname{SSR}\left(\mathrm{Y}_{\mathrm{h}}\right)=\frac{\mathrm{J}-1}{\sum_{\mathrm{i}=1}^{\mathrm{I}} \mathrm{c}_{\mathrm{hi}}^{2}} \sum_{\mathrm{i}=1}^{\mathrm{I}} \mathrm{c}_{\mathrm{hi}}^{2} \mathrm{~S}_{\mathrm{i}}^{2}$, for $\mathrm{h}=1, \ldots,(\mathrm{I}-1)$

with (J-1) degrees of freedom, and

$\mathrm{S}_{\mathrm{i}}^{2}=\frac{1}{\mathrm{~J}-1}[\underbrace{[\sum_{\mathrm{j=1}}^{\mathrm{J}} \mathrm{y}_{\mathrm{ij}}^{2}-\underbrace{\left.\mathrm{J} \mathrm{y}_{\mathrm{ij}}\right)^{2}}_{\mathrm{j}=1}}_{\mathrm{SST}_{\mathrm{i}}}]=\frac{\mathrm{SST}_{\mathrm{i}}}{\mathrm{J}-1}$,

where $\mathrm{SST}_{\mathrm{i}}$ is the i-esimal treatment sum of squares. Thus, the residual mean square for $\mathrm{Y}_{\mathrm{h}}\left(\mathrm{MSR}\left(\mathrm{Y}_{\mathrm{h}}\right)\right)$ is given by:

$$
\operatorname{MSR}\left(\mathrm{Y}_{\mathrm{h}}\right)=\frac{1}{\mathrm{~J}-1}\left[\frac{1}{\sum_{\mathrm{i}=1}^{\mathrm{I}} \mathrm{c}_{\mathrm{hi}}^{2}} \sum_{\mathrm{i}=1}^{\mathrm{I}} \mathrm{c}_{\mathrm{hi}}^{2} \mathrm{~S}_{\mathrm{i}}^{2}\right]
$$

with $n_{h}$ degrees of freedom, obtained by the application of the Satterthwaite $(1941,1946)$ formula, and thus,

$\mathrm{n}_{\mathrm{h}}=\frac{\left(\sum_{\mathrm{i}=1}^{\mathrm{I}} \mathrm{c}_{\mathrm{hi}}^{2} \mathrm{~S}_{\mathrm{i}}^{2}\right)^{2}}{\sum_{\mathrm{i}=1}^{\mathrm{I}} \frac{\left(\mathrm{c}_{\mathrm{hi}}^{2} \mathrm{~S}_{\mathrm{i}}^{2}\right)^{2}}{\mathrm{~J}-1}}$.

SSResidual $=\sum_{\mathrm{h}=1}^{\mathrm{I}-1} \operatorname{SSR}\left(\mathrm{Y}_{\mathrm{h}}\right)+\mathrm{SSR}($ among replications $)$,

with I(J-1) degrees of freedom, and the SSR(among replications) is the residual sum of squares among replications, so that

$\operatorname{SSR}($ among replications $)=\frac{\mathrm{J}-1}{\mathrm{I}} \sum_{\mathrm{i}=1}^{\mathrm{I}} \mathrm{S}_{\mathrm{i}}^{2}$,

with (J-1) degrees of freedom and that residual mean square among replications (MSR (among replications) is

$\operatorname{MSR}$ (among replications) $=\frac{1}{\mathrm{~J}-1}\left[\frac{\mathrm{J}-1}{\mathrm{I}} \sum_{\mathrm{i}=1}^{\mathrm{I}} \mathrm{S}_{\mathrm{i}}^{2}\right]=\frac{\sum_{\mathrm{i}=1}^{\mathrm{I}} \mathrm{S}_{\mathrm{i}}^{2}}{\mathrm{I}}$

It was also observed that
MSResidual $=\operatorname{MSR}$ (among replications) $=\frac{1}{\mathrm{I}-1} \sum_{\mathrm{h}=1}^{(\mathrm{I}-1)} \operatorname{MSR}\left(\mathrm{Y}_{\mathrm{h}}\right)$.
Therefore, the hypotheses $\mathrm{H}_{0}: \mathrm{Y}_{h}=0$ vs. $\mathrm{H}_{\mathrm{a}}: \mathrm{Y}_{\mathrm{h}} \neq 0$, for $h=1, \ldots,(I-1)$ were tested by the application of the $\mathrm{F}$ test, and the calculated $\mathrm{F}$ value was obtained through the expression:

$$
\mathrm{F}_{\mathrm{h}}=\frac{\operatorname{MS}\left(\mathrm{Y}_{\mathrm{h}}\right)}{\operatorname{MSR}\left(\mathrm{Y}_{\mathrm{h}}\right)} \sim \mathrm{F}_{\left(1, \mathrm{n}_{\mathrm{h}}\right)},
$$

where $\mathrm{MS}\left(\mathrm{Y}_{h}\right)$ is the mean square of the $\mathrm{Y}_{h}$ component, with one degree of freedom, obtained as follows:

$\operatorname{MS}\left(\mathrm{Y}_{\mathrm{h}}\right)=\frac{\mathrm{SS}\left(\mathrm{Y}_{\mathrm{h}}\right)}{1} ; \mathrm{SS}\left(\mathrm{Y}_{\mathrm{h}}\right)=\frac{\hat{\mathrm{Y}}_{\mathrm{h}}^{2}}{J \sum_{\mathrm{i}=1}^{\mathrm{I}} \mathrm{c}_{\mathrm{hi}}^{2}}=\frac{\left(\sum_{\mathrm{i}=1}^{\mathrm{I}} \mathrm{c}_{\mathrm{hi}} \mathrm{y}_{\mathrm{i} .}\right)^{2}}{J \sum_{\mathrm{i}=1}^{\mathrm{L}} \mathrm{c}_{\mathrm{hi}}^{2}}$, and the followed the approximated $\mathrm{F}$ distributions with one degree of freedom was referred to $M S\left(Y_{h}\right)$ with $n_{h}$ degrees of freedom obtained by the Satterthwaite (1941, 1946) formula and to $\operatorname{MSR}\left(\mathrm{Y}_{\mathrm{h}}\right)$ as verified by Nogueira (1984). The verification was accomplished through the application of the simulation method developed by Godoi (1978), based on Box and Miller (1958), to variables with normal and one-dimensional distributions. The Chi-square test was applied to verify the adherence of $\mathrm{F}_{\mathrm{h}}$ with the $\mathrm{F}_{\left(1, \mathrm{n}_{\mathrm{h}}\right)}$ distributions.

\section{Results and Discussion}

\section{Completely randomized design}

The experimental data shown in Table 1, cited by Nogueira (1984), refer to sorghum total dry matter yield, first cropping (g per pot) obtained from a completely randomized design experiment, with eight treatments and four replications, so that: Total for each treatment $\rightarrow \mathrm{y}_{\mathrm{i} .}=\sum_{\mathrm{j}=1}^{\mathrm{J}=4} \mathrm{y}_{\mathrm{ij}}$

Sum of squares error for each treatment

$\rightarrow \operatorname{SST}_{\mathrm{i}}=\sum_{\mathrm{j}=1}^{\mathrm{J}=4} \mathrm{y}_{\mathrm{ij}}^{2}-\frac{\left(\sum_{\mathrm{j}=1}^{\mathrm{J}=4} \mathrm{y}_{\mathrm{ij}}\right)^{2}}{4}$,

Table 1 - Sorghum plant total dry matter yields (g per pot), mean deviation sum of squares and variance estimate for each treatment (eight treatments, average of four replications).

\begin{tabular}{lcccrrr}
\hline Treatment $(\mathrm{i})$ & $\begin{array}{c}\text { Fertilization } \\
(\mathrm{N}+\mathrm{K}+\mathrm{S}+\mathrm{Mg}+\text { Micro) }\end{array}$ & $\begin{array}{c}\text { P-rates (Triple- } \\
\text { superphosphate }(\mathrm{ppm})\end{array}$ & $\begin{array}{c}\text { P-fertilizer } \\
\text { application }\end{array}$ & $\begin{array}{c}\text { Total } \\
\mathrm{y}_{\mathrm{i}}\end{array}$ & $\mathrm{SST}_{\mathrm{i}}$ & $\begin{array}{c}\mathrm{S}_{\mathrm{i}}^{2} \\
\text { with } 3 \mathrm{DF}\end{array}$ \\
\hline 1 & no & 0 & & 2.68 & 0.083 & 0.027 \\
2 & yes & 0 & & 1.91 & 0.049 & 0.016 \\
3 & yes & 50 & Located & 181.13 & 52.141 & 17.380 \\
4 & yes & 100 & Located & 226.93 & 144.207 & 48.069 \\
\hline 5 & yes & 50 & Located & 236.98 & 37.045 & 12.348 \\
6 & yes & 100 & Incorporated & 169.91 & 4.265 & 1.422 \\
7 & yes & 200 & Incorporated & 195.85 & 45.030 & 15.010 \\
\hline 8 & yes & & Incorporated & 216.51 & 537.337 & 179.112 \\
\hline
\end{tabular}

Sci. Agric. (Piracicaba, Braz.), v.67, n.1, p.117-125, January/February 2010 
with (4 -1) degrees of freedom, where $y_{i j}$ is the observed value (g per pot) of the $\mathrm{i}$-esimal treatment in the $\mathrm{j}$-esimal replication.

The variance for each treatment is given by $\mathrm{S}_{\mathrm{i}}^{2}=\frac{1}{4-1} \mathrm{SST}_{\mathrm{i}}$, with (4-1) degrees of freedom and $\mathrm{i}=1$, ..., 8 .

Preliminary analyses of variance results are presented in Table 2. Seven degrees of freedom for treatments and the sum of squares for treatments were decomposed according to the following group of orthogonal contrasts of interest: $\mathrm{Y}_{1}$ : control treatments versus located and incorporated P-rates; $\mathrm{Y}_{2}$ : among controls; $\mathrm{Y}_{3}$ : Located versus incorporated P-rates; $\mathrm{Y}_{4}$ : Linear effect of located P-rates; $\mathrm{Y}_{5}$ : Quadratic effect of located P-rates; $\mathrm{Y}_{6}$ : Linear effect of incorporated P-rates; $\mathrm{Y}_{7}$ : Quadratic effect of incorporated P-rates.

Contrasts $\mathrm{Y}_{4}$ and $\mathrm{Y}_{5}$ provided the located-P treatment effect and contrasts $\mathrm{Y}_{6}$ and $\mathrm{Y}_{7}$, the incorporated-P treatment effect. The coefficients of applied contrasts and some results are shown in Table 3. As P-rates are not equidistant, the coefficients attributed to $\mathrm{Y}_{4}, \mathrm{Y}_{5}, \mathrm{Y}_{6}$ and $\mathrm{Y}_{7}$ contrasts were obtained using the orthogonal polynomial coefficient procedure for non-equidistant levels developed by Nogueira (1978) and cited by Nogueira (2007). The new analysis of variance with $\mathrm{F}$ test results without specific residue application is presented in Table 4.

Table 2 - Preliminary analysis of variance for the sorghum experiment

\begin{tabular}{lcrr}
\hline Sources of Variation & DF & \multicolumn{1}{c}{ SS } & \multicolumn{1}{c}{ MS } \\
\hline Treatment & 7 & $16,220.4155$ & $2,317.2022$ \\
Residual & 24 & 820.1616 & 34.1734 \\
\hline Total & 31 & $17,040.5771$ & \\
\hline
\end{tabular}

Note: DF is degrees of freedom; SS is Sum of Squares; MS is Mean Square.
If the model homoscedasticity assumption is satisfied, that is, if it is possible to consider that statistically $\mathrm{S}_{1}^{2}=\mathrm{S}_{2}^{2}=\cdots=\mathrm{S}_{8}^{2}=\mathrm{S}^{2}=$ MSResidual, the analysis presented in Table 4 is perfectly valid.

In order to verify the experimental data homoscedasticity, the Bartlett test was applied (among other tests), which is appropriate to test the following hypotheses:

$H_{0}: \sigma_{1}^{2}=\cdots=\sigma_{8}^{2}$ vs. $H_{a}: \sigma_{i}^{2} \neq \sigma_{i^{\prime}}^{2}$, for at least one $i \neq i^{\prime}$.

The hypothesis $H_{0}: \sigma_{1}^{2}=\cdots=\sigma_{8}^{2}$ was rejected at $p$ value $<0.005$ significance level, evidencing significant differences among variances due to the replications within treatments, characterizing the presence of heteroscedasticity. Once heteroscedasticity was evidenced, a procedure should be applied to overcome this situation. One alternative was the use of the specific residue as the $\mathrm{F}$ test denominator, to test each contrast defined in Table 3. This procedure consisted of the decomposition of all residual degrees of freedom (24), and consequently, the residual sum of squares obtaining the specific residue for each contrast:

$$
\operatorname{SSR}\left(Y_{h}\right)=\frac{4-1}{\sum_{i=1}^{I} c_{h i}^{2}} \sum_{i=1}^{I=8} c_{h i}^{2} S_{i}^{2}, \text { for } h=1, \ldots,(8-1)
$$

with (4 -1) degrees of freedom and

$$
\operatorname{MSR}\left(Y_{h}\right)=\frac{\operatorname{SSR}\left(Y_{h}\right)}{4-1}=\frac{1}{4-1}\left[\frac{(4-1)}{\sum_{i=1}^{I=8} c_{h i}^{2}} \sum_{i=1}^{I=8} c_{h i}^{2} S_{i}^{2}\right] \text {, with } n_{h}
$$

degrees of freedom obtained through the application of the Satterthwaite $(1941,1946)$ formula

$$
\mathrm{n}_{\mathrm{h}}=\frac{\left[\sum_{\mathrm{i}=1}^{\mathrm{I}=8} \mathrm{c}_{\mathrm{hi}}^{2} \mathrm{~S}_{\mathrm{i}}^{2}\right]^{2}}{\sum_{\mathrm{i}=1}^{\mathrm{I}=8} \frac{\left[\mathrm{c}_{\mathrm{hi}}^{2} \mathrm{~S}_{\mathrm{i}}^{2}\right]^{2}}{4-1}}
$$

\begin{tabular}{|c|c|c|c|c|c|c|c|c|}
\hline \multirow{2}{*}{$\begin{array}{l}\text { Treatment } \\
\text { (i) }\end{array}$} & \multirow{2}{*}{$\bar{y}_{i}$} & \multicolumn{7}{|c|}{ Orthogonal contrast coefficients, $c_{h i}, h=1, \ldots, 7$} \\
\hline & & $\mathrm{c}_{1 \mathrm{i}}$ & $\mathrm{c}_{2 \mathrm{i}}$ & $\mathrm{c}_{3 \mathrm{i}}$ & $\mathrm{c}_{4 \mathrm{i}}$ & $\mathrm{c}_{5 \mathrm{i}}$ & $\mathrm{c}_{6 \mathrm{i}}$ & $\mathrm{c}_{7 \mathrm{i}}$ \\
\hline 1 & 0.67 & 3 & 1 & 0 & 0 & 0 & 0 & 0 \\
\hline 2 & 0.45 & 3 & -1 & 0 & 0 & 0 & 0 & 0 \\
\hline 3 & 45.28 & -1 & 0 & 1 & -4 & 18 & 0 & 0 \\
\hline 4 & 56.73 & -1 & 0 & 1 & -1 & -27 & 0 & 0 \\
\hline 5 & 59.25 & -1 & 0 & 1 & 5 & 9 & 0 & 0 \\
\hline 6 & 42.48 & -1 & 0 & -1 & 0 & 0 & -4 & 18 \\
\hline 7 & 48.96 & -1 & 0 & -1 & 0 & 0 & -1 & -27 \\
\hline 8 & 54.13 & -1 & 0 & -1 & 0 & 0 & 5 & 9 \\
\hline$\hat{\mathrm{Y}}_{\mathrm{h}}$ & & -303.3800 & 0.1900 & 15.6900 & 19.4500 & -8.7400 & 17.2600 & -3.3500 \\
\hline $\mathrm{SS}\left(\mathrm{Y}_{\mathrm{h}}\right)$ & & $15,340.4097$ & 0.0741 & 164.1697 & 324.3982 & 118.7572 & 255.2015 & 17.4052 \\
\hline $\mathrm{DF}\left(\mathrm{Y}_{\mathrm{h}}\right)$ & & 1 & 1 & 1 & 1 & 1 & 1 & 1 \\
\hline
\end{tabular}

Table 3 - Application of orthogonal contrasts to the sorghum experiment.

Note: $\bar{y}_{i}=\frac{y_{i .}}{4}$ is the i-esimal treatment mean; $y_{i .}=\sum_{j=1}^{J=4} y_{i j}$, total of the i-esimal treatment.

Sci. Agric. (Piracicaba, Braz.), v.67, n.1, p.117-125, January/February 2010 
SSResidual $=\sum_{\mathrm{h}=1}^{8-1} \mathrm{SSR}\left(\mathrm{Y}_{\mathrm{h}}\right)+\operatorname{SSR}($ among replications), with $8(4-1)$ degrees of freedom. And SSR(among repli-

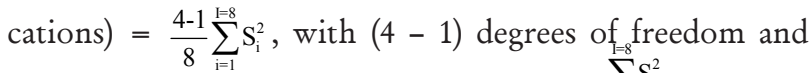
MSR (among replications) $=\frac{1}{4-1}\left[\frac{4-1}{8} \sum_{\mathrm{i}=1}^{\mathrm{I}=8} \mathrm{~S}_{\mathrm{i}}^{2}\right]=\frac{\sum_{\mathrm{i}=1}^{1-8} \mathrm{~S}_{\mathrm{i}}^{2}}{8}$.
Thus, the hypothesis $\mathrm{H}_{0}: \mathrm{Y}_{h}=0$ vs. $\mathrm{H}_{\mathrm{a}}: \mathrm{Y}_{\mathrm{h}} \neq 0$, for $h=1, \ldots,(8-1)$, will be tested by the application of the $F$ test and that $F_{h}=\frac{\operatorname{MS}\left(Y_{h}\right)}{\operatorname{MSR}\left(Y_{h}\right)} \sim F_{\left(1, n_{h}\right)}$, as observed by Nogueira (1984). Results are shown in Table 5, where the values in [ ], found in DF (degrees of freedom) col-

Table 4 - Analysis of variance with treatment decomposition of seven degrees of freedom decomposition in orthogonal contrasts without specific residue application.

\begin{tabular}{|c|c|c|c|c|}
\hline Sources of Variation & DF & SS & MS & F test \\
\hline Controls vs P-treatments (Y1) & 1 & $15,340.4097$ & $15,340.4097$ & $448.90 * *$ \\
\hline Between controls (Y2) & 1 & 0.0741 & 0.0741 & 0.00 \\
\hline Located-P vs Incorporated-P (Y3) & 1 & 164.1697 & 164.1697 & $4.80 *$ \\
\hline Located-P (Y4 + Y5) & 2 & 443.1554 & 221.5778 & $6.48 \% *$ \\
\hline Located- P linear effect (Y4) & 1 & 324.3982 & 324.3982 & $9.49 * \%$ \\
\hline Located-P quadratic effect (Y5) & 1 & 118.7572 & 118.7572 & 3.48 \\
\hline Incorporated-P (Y6 + Y7) & 2 & 272.6066 & 136.3033 & $3.99 \%$ \\
\hline Incorporated-P linear effect (Y6) & 1 & 255.2015 & 255.2015 & $7.47 \%$ \\
\hline Incorporated-P quadratic effect (Y7) & 1 & 17.4052 & 17.4052 & 0.51 \\
\hline (Treatments) & (7) & $(16,220.4155)$ & $2,317.2022$ & 67.81 \\
\hline Residual & 24 & 820.1616 & 34.1734 & \\
\hline Total & 31 & $17,040.5771$ & & \\
\hline
\end{tabular}

Note: *significance by $(0.01<p$-Value $\leq 0.05)$; **significance by $(p$-Value $\leq 0.01)$.

Table 5 - Analysis of variance with specific residue application.

\begin{tabular}{|c|c|c|c|c|}
\hline Sources of Variation & DF & SS & MS & F test \\
\hline Controls vs P-treatments (Y1) & 1 & $15,340.4097$ & $15,340.4097$ & $1,344.95 \% *$ \\
\hline Between controls (Y2) & 1 & 0.0741 & 0.0741 & 3.34 \\
\hline Located-P vs Incorporated-P (Y3) & 1 & 164.1697 & 164.1697 & 3.60 \\
\hline Located-P (Y4 + Y5) & 2 & 443.1554 & 221.5778 & $8.54 *$ \\
\hline Located- $P$ linear effect $(\mathrm{Y} 4)$ & 1 & 324.3982 & 324.3982 & $21.46^{*}$ \\
\hline Located-P quadratic effect (Y5) & 1 & 118.7572 & 118.7572 & 3.23 \\
\hline Incorporated-P (Y6 + Y7) & 2 & 272.6066 & 136.3033 & 2.09 \\
\hline Incorpor.-P linear effect (Y6) & 1 & 255.2015 & 255.2015 & 2.37 \\
\hline Incorpor.-P quadratic effect (Y7) & 1 & 17.4052 & 17.4052 & 0.76 \\
\hline (Treatments) & (7) & $(16,220.4155)$ & $2,317.2022$ & 67.81 \\
\hline $\mathrm{R}\left(\mathrm{Y}_{1}\right)$ & $3[7]$ & 34.2177 & 11.4059 & \\
\hline $\mathrm{R}\left(\mathrm{Y}_{2}\right)$ & $3[6]$ & 0.0664 & 0.0222 & \\
\hline $\mathrm{R}\left(\mathrm{Y}_{3}\right)$ & $3[7]$ & 136.6710 & 45.5571 & \\
\hline $\mathrm{R}($ Located-P) & $6[5]$ & 155.5971 & 25.9321 & \\
\hline $\mathrm{R}\left(\mathrm{Y}_{4}\right)$ & $3[7]$ & 45.3481 & 15.1160 & \\
\hline $\mathrm{R}\left(\mathrm{Y}_{5}\right)$ & $3[4]$ & 110.2490 & 36.7496 & \\
\hline $\mathrm{R}$ (Incorporated-P) & $6[8]$ & 391.0889 & 65.1814 & \\
\hline $\mathrm{R}\left(\mathrm{Y}_{6}\right)$ & $3[3]$ & 322.5410 & 107.5140 & \\
\hline $\mathrm{R}\left(\mathrm{Y}_{7}\right)$ & $3[6]$ & 68.5479 & 22.8493 & \\
\hline $\mathrm{R}$ (among replications) & 3 & 102.520 & 34.1734 & \\
\hline (Residual) & $(24)$ & (820.1616) & 34.1734 & \\
\hline Total & 31 & $17,040.5771$ & & \\
\hline
\end{tabular}

Note: *significance by $(0.01<p$-Value $\leq 0.05)$; **significance by $(p$-Value $\leq 0.01)$.

Sci. Agric. (Piracicaba, Braz.), v.67, n.1, p.117-125, January/February 2010 
umn refer to the effective degrees of freedom $-n_{h}$, obtained by the Satterthwaite formula and applied in the F test.

It was observed that

MSResidual $=$ MSR (among replications) $=\frac{1}{7} \sum_{\mathrm{h}=1}^{(8-1)} \mathrm{MSR}$ $\left(\mathrm{Y}_{\mathrm{h}}\right)=34.1734$.

The $\mathrm{F}$ test values presented in Table 4 were obtained having MSResidual as denominator, with 24 degrees of freedom. The results presented in Tables 4 and 5 are different as well as some of the conclusions. This fact is important due to the presence of heteroscedasticity, because in Table 4, the MSResidual corresponds to the $\operatorname{MSR}\left(\mathrm{Y}_{\mathrm{h}}\right)$ arithmetic mean; and in Table 5, the values obtained for $\operatorname{MSR}\left(\mathrm{Y}_{\mathrm{h}}\right)$ were different. In the presence of homoscedasticity the values obtained for $\operatorname{MSR}\left(\mathrm{Y}_{\mathrm{h}}\right)$ are very close to the ones obtained for MSResidual. The use of the specific residue procedure showed to be an interesting alternative to be applied when irregular heteroscedasticity is present, providing trustworthy results.

\section{Randomized complete block design}

In order to illustrate the specific residue procedure application on data analyses of a randomized complete block design experiment, the following experimental data were considered: yields of eight potato varieties $\left(\mathrm{t} \mathrm{ha}^{-1}\right)$ distributed in five blocks (Table 6).

The Bartlett test was applied to verify the variance homogeneity hypothesis, which was rejected, thus evidencing the presence of variance heterogeneity among treatments. Due to this fact and considering that experimental errors followed a normal distribution, the specific residue procedure was applied as an alternative for this data analysis. The initial analysis of variance is shown in Table 7.

Seven degrees of freedom and the variety sum of squares were decomposed in a group of orthogonal contrasts according to the high and low productivity criterion. Then, the potato varieties were divided into two groups and the high productivity potato group consisted of the varieties: (3) B1-52, (4) Huinkul, (5) B116-51; (6) B72-53 A and (7) S. Rafaela; and the low productivity potato group consisted of the varieties: (1) Kennebec, (2)
B25-50E and (8) Buena Vista. Thus, the group of orthogonal contrasts built up according to the productivity criterion was: $\mathrm{Y}_{1}$ : High productivity varieties (varieties 3, 4, 5, 6 and 7) versus Low productivity varieties (varieties 1, 2 and 8 ); $\mathrm{Y}_{2}$ : Variety 7 versus varieties 3, 4, 5 and 6; $\mathrm{Y}_{3}$ : Varieties 4 and 6 versus varieties 3 and 5 ; $Y_{4}$ : Between varieties 4 and $6 ; \mathrm{Y}_{5}$ : Between varieties 3 and $5 ; \mathrm{Y}_{6}$ : Variety 1 versus varieties 2 and $8 ; \mathrm{Y}_{7}$ : Between varieties 2 and 8.

The orthogonal contrasts $\mathrm{Y}_{2}, \mathrm{Y}_{3}, \mathrm{Y}_{4}$ and $\mathrm{Y}_{5}$ provided the high productivity variety effect with four degrees of freedom, and the contrasts $\mathrm{Y}_{6}$ and $\mathrm{Y}_{7}$ provided the low productivity variety effect with two degrees of freedom. The coefficients of the applied contrasts, the contrast estimates and the sum of squares obtained are shown in Table 8.

Twenty eight degrees of freedom and the residual sum of squares were decomposed according to the $\mathrm{Y}(\mathrm{h})$ components, resulting the $\mathrm{Y}(\mathrm{h})$ specific residues given by:

$$
\operatorname{SSR}\left(\mathrm{Y}_{\mathrm{h}}\right)=\frac{1}{\sum_{\mathrm{i}=1}^{\mathrm{I}=8} \mathrm{c}_{\mathrm{hi}}^{2}}\left[\sum_{\mathrm{j}=1}^{\mathrm{J}=5} \hat{\mathrm{Y}}_{\mathrm{hj}}^{2}-\frac{\hat{\mathrm{Y}}_{\mathrm{h}}^{2}}{5}\right] \text {, }
$$

with $(5-1)=4$ degrees of freedom and $\hat{Y}_{h j}$ is the $Y_{h j}$ contrast estimate, corresponding to the $\mathrm{Y}_{\mathrm{h}}$ contrast application in the block $\mathrm{j}$, for $\mathrm{j}=1, \ldots, \mathrm{J}=5$,

$\hat{\mathrm{Y}}_{\mathrm{hj}}=\sum_{\mathrm{i}=1}^{\mathrm{I}=8} \mathrm{c}_{\mathrm{hi}} \mathrm{y}_{\mathrm{ij}}$, such that $\sum_{\mathrm{i}=1}^{\mathrm{I}} \mathrm{c}_{\mathrm{hi}}=0$ and

$\hat{\mathrm{Y}}_{\mathrm{h}}=\sum_{\mathrm{j}=1}^{\mathrm{J}=5} \hat{\mathrm{Y}}_{\mathrm{hj}}=\sum_{\mathrm{i}=1}^{\mathrm{I}=8} \mathrm{c}_{\mathrm{hi}} \mathrm{y}_{\mathrm{i} .}$,

where $y_{i j}$ is the observed value related to variety $i$ in block j; $\hat{Y}_{\mathrm{h}}$ is the h-esimal contrast estimate, for $\mathrm{h}=1$, $\ldots,(8-1)=7$ and $\mathrm{y}_{\mathrm{i} .}=\sum_{\mathrm{j}=1}^{\mathrm{J}=5} \mathrm{y}_{\mathrm{ij}}$. The values referred to $\mathrm{y}_{\mathrm{ij}}$ and the $Y_{h}$ coefficients for the $\hat{Y}_{h j}$ calculus are presented in Table 9.

The results referred to $\hat{\mathrm{Y}}_{\mathrm{hj}}$ and $\hat{\mathrm{Y}}_{\mathrm{h}}$ estimates and $\operatorname{SSR}\left(\mathrm{Y}_{\mathrm{h}}\right)$ values are presented in Table 10, as follows:

It was observed that $\sum_{\mathrm{h}=1}^{8-1} \mathrm{SSR}\left(\mathrm{Y}_{\mathrm{h}}\right)=\mathrm{SQResidual}=$ 348.324, with (8-1)(5-1) $=28$ degrees of freedom.

Also that $\operatorname{MSR}\left(\mathrm{Y}_{\mathrm{h}}\right)=\frac{1}{5-1} \operatorname{SSR}\left(\mathrm{Y}_{\mathrm{h}}\right)$, with $(5-1)=4$ degrees of freedom.

Thus, the hypotheses $\mathrm{H}_{0}: \mathrm{Y}_{\mathrm{h}}=0$ vs. $\mathrm{H}_{\mathrm{a}}: \mathrm{Y}_{\mathrm{h}} \neq 0$, for

Table 6 - Potato variety yields $\left(\mathrm{tha}^{-1}\right)$.

\begin{tabular}{|c|c|c|c|c|c|c|}
\hline \multirow{2}{*}{ Variety (i) } & \multicolumn{5}{|c|}{ Blocks } & \multirow{2}{*}{$\begin{array}{c}\text { Variance } \\
\mathrm{S}_{\mathrm{i}}^{2}\end{array}$} \\
\hline & 1 & 2 & 3 & 4 & 5 & \\
\hline (1) Kennebec & 11.750 & 7.950 & 10.700 & 12.050 & 12.300 & 31.0798 \\
\hline (2) B25-50 E & 12.075 & 16.250 & 16.500 & 8.950 & 14.575 & 2.1561 \\
\hline (3) B1-52 & 16.150 & 30.025 & 22.275 & 10.975 & 23.500 & 10.5313 \\
\hline (4) Huinkul & 20.550 & 30.125 & 25.050 & 15.600 & 23.225 & 2.2617 \\
\hline (5) B116-51 & 15.275 & 30.575 & 22.500 & 13.075 & 23.200 & 9.3295 \\
\hline (6) B72-53 A & 17.350 & 27.800 & 22.800 & 12.975 & 19.925 & 3.1558 \\
\hline (7) S. Rafaela & 17.125 & 29.400 & 25.450 & 12.200 & 23.225 & 7.5243 \\
\hline (8) Buena Vista & 11.925 & 10.650 & 12.425 & 12.400 & 13.000 & 21.0424 \\
\hline
\end{tabular}

Sci. Agric. (Piracicaba, Braz.), v.67, n.1, p.117-125, January/February 2010 
Table 7 - Analysis of variance of potato yield.

\begin{tabular}{lrrr}
\hline Sources of Variation & DF & \multicolumn{1}{c}{ SS } & MS \\
\hline Blocks & 4 & 542.2406 & \\
Varieties & 7 & 793.9257 & 113.4180 \\
Residual & 28 & 348.3238 & 12.4401 \\
\hline Total & 39 & $1,684.6119$ & \\
\hline
\end{tabular}

$\mathrm{h}=1, \ldots,(8-1)$, were then tested by the application of the $F$ test, $F_{h}=\frac{\operatorname{MS}\left(Y_{h}\right)}{\operatorname{MSR}\left(Y_{h}\right)} \sim F_{(1,(5-1))}$.

The analysis of variance obtained with the specific residue procedure application is presented in Table 11. Significant $F$ test values for $\mathrm{Y}_{1}$ and $\mathrm{Y}_{4}$ contrasts were observed, evidencing they differ from zero.

Table 8 - Coefficients of contrasts, estimates and contrast sum of squares for the potato yield experiment.

\begin{tabular}{|c|c|c|c|c|c|c|c|c|}
\hline \multirow{2}{*}{$\begin{array}{l}\text { Treatment } \\
\text { (i) }\end{array}$} & \multirow{2}{*}{$\begin{array}{c}\text { Total for } 5 \\
\text { blocks }\end{array}$} & \multicolumn{7}{|c|}{ Orthogonal contrast coefficients, $c_{h i}, h=1, \ldots, 7$} \\
\hline & & $\mathrm{c}_{1 \mathrm{i}}$ & $\mathrm{c}_{2 \mathrm{i}}$ & $\mathrm{c}_{3 \mathrm{i}}$ & $\mathrm{c}_{4 \mathrm{i}}$ & $\mathrm{c}_{5 \mathrm{i}}$ & $\mathrm{c}_{6 \mathrm{i}}$ & $\mathrm{c}_{7 \mathrm{i}}$ \\
\hline (1) Kennebec & 54.750 & -5 & 0 & 0 & 0 & 0 & 2 & 0 \\
\hline (2) $\mathrm{B} 25-50 \mathrm{E}$ & 68.350 & -5 & 0 & 0 & 0 & 0 & -1 & 1 \\
\hline (3) B1-52 & 102.350 & 3 & -1 & -1 & 0 & 1 & 0 & 0 \\
\hline (4) Huinkul & 114.550 & 3 & -1 & 1 & 1 & 0 & 0 & 0 \\
\hline (5) B116-51 & 104.625 & 3 & -1 & -1 & 0 & -1 & 0 & 0 \\
\hline (6) $\mathrm{B} 72-53 \mathrm{~A}$ & 100.850 & 3 & -1 & 1 & -1 & 0 & 0 & 0 \\
\hline (7) S. Rafaela & 107.400 & 3 & 4 & 0 & 0 & 0 & 0 & 0 \\
\hline (8) Buena Vista & 60.700 & -5 & 0 & 0 & 0 & 0 & -1 & -1 \\
\hline$\hat{\mathrm{Y}}_{\mathrm{h}}$ & & 672.050 & 6.650 & 7.850 & 13.700 & -1.700 & -19.550 & 7.650 \\
\hline $\mathrm{SS}\left(\mathrm{Y}_{\mathrm{h}}\right)$ & & 752.752 & 0.442 & 3.081 & 18.769 & 0.289 & 12.740 & 5.852 \\
\hline $\mathrm{DF}\left(\mathrm{Y}_{\mathrm{h}}\right)$ & & 1 & 1 & 1 & 1 & 1 & 1 & 1 \\
\hline
\end{tabular}

Table 9 - Observed values $\left(\mathrm{y}_{\mathrm{ij}}\right)$ and $\mathrm{Y}_{\mathrm{h}}$-coefficients for $\hat{\mathrm{Y}}_{\mathrm{hj}}$ estimation.

\begin{tabular}{|c|c|c|c|c|c|c|c|c|c|c|c|c|}
\hline \multicolumn{6}{|c|}{ Observed values, $\mathrm{y}_{\mathrm{ij}}$} & \multirow{2}{*}{\multicolumn{7}{|c|}{$Y_{h}$ coefficients }} \\
\hline \multirow{2}{*}{ Variety (i) } & \multicolumn{5}{|c|}{ Blocks (j) } & & & & & & & \\
\hline & 1 & 2 & 3 & 4 & 5 & $\mathrm{c}_{1 \mathrm{i}}$ & $\mathrm{c}_{2 \mathrm{i}}$ & $c_{3 i}$ & $\mathrm{c}_{4 \mathrm{i}}$ & $\mathrm{c}_{5 \mathrm{i}}$ & $\mathrm{c}_{6 \mathrm{i}}$ & $c_{7 \mathrm{i}}$ \\
\hline (1) Kennebec & 11.750 & 7.950 & 10.700 & 12.050 & 12.300 & -5 & 0 & 0 & 0 & 0 & 2 & 0 \\
\hline (2) $\mathrm{B} 25-50 \mathrm{E}$ & 12.075 & 16.250 & 16.500 & 8.950 & 14.575 & -5 & 0 & 0 & 0 & 0 & -1 & 1 \\
\hline (3) B1-52 & 16.150 & 30.025 & 22.275 & 10.975 & 23.500 & 3 & -1 & -1 & 0 & 1 & 0 & 0 \\
\hline (4) Huinkul & 20.550 & 30.125 & 25.050 & 15.600 & 23.225 & 3 & -1 & 1 & 1 & 0 & 0 & 0 \\
\hline (5) B116-51 & 15.275 & 30.575 & 22.500 & 13.075 & 23.200 & 3 & -1 & -1 & 0 & -1 & 0 & 0 \\
\hline (6) $\mathrm{B} 72-53 \mathrm{~A}$ & 17.350 & 27.800 & 22.800 & 12.975 & 19.925 & 3 & -1 & 1 & -1 & 0 & 0 & 0 \\
\hline (7) S. Rafaela & 17.125 & 29.400 & 25.450 & 12.200 & 23.225 & 3 & 4 & 0 & 0 & 0 & 0 & 0 \\
\hline (8) Buena Vista & 11.925 & 10.650 & 12.425 & 12.400 & 13.000 & -5 & 0 & 0 & 0 & 0 & -1 & -1 \\
\hline
\end{tabular}

Table 10 - Estimation of $\hat{\mathrm{Y}}_{\mathrm{hj}}$ and $\hat{\mathrm{Y}}_{\mathrm{h}}$ and $\operatorname{SSR}\left(\mathrm{Y}_{\mathrm{h}}\right)$ values.

\begin{tabular}{|c|c|c|c|c|c|c|}
\hline \multirow{3}{*}{ (h) $\hat{Y}_{h}$} & \multicolumn{5}{|c|}{$\hat{\mathrm{Y}}_{\mathrm{hj}}=\sum_{\mathrm{i}=1}^{\mathrm{I}=8} \mathrm{c}_{\mathrm{hi}} \mathrm{y}_{\mathrm{ij}}$} & \multirow{3}{*}{$\operatorname{SSR}\left(\mathrm{Y}_{\mathrm{h}}\right)$} \\
\hline & \multicolumn{5}{|c|}{ Blocks (j) } & \\
\hline & 1 & 2 & 3 & 4 & 5 & \\
\hline (1) 672.05 & 80.600 & 269.525 & 156.1 & 27.475 & 138.35 & 275.605 \\
\hline (2) 6.65 & -0.825 & -0.925 & 9.175 & -3.825 & 3.050 & 5.04027 \\
\hline (3) 7.85 & 6.475 & -2.675 & 3.075 & 4.525 & -3.550 & 19.8226 \\
\hline (4) 13.70 & 3.200 & 2.325 & 2.250 & 2.625 & 3.300 & 0.47538 \\
\hline (5) -1.70 & 0.875 & -0.550 & -0.225 & -2.100 & 0.300 & 2.52037 \\
\hline (6) -19.55 & -0.500 & -1.100 & -7.525 & 2.750 & -3.275 & 19.9539 \\
\hline (7) 7.65 & 0.150 & 5.600 & 4.075 & -3.450 & 1.275 & 24.9059 \\
\hline SSResidual & & & & & & 348.324 \\
\hline
\end{tabular}

Sci. Agric. (Piracicaba, Braz.), v.67, n.1, p.117-125, January/February 2010 
Table 11 - Analyses of variance with specific residue procedure application.

\begin{tabular}{lcrrrc}
\hline Sources of Variation & DF & \multicolumn{1}{c}{ SS } & MS & F Test & $\hat{Y}_{h}$ \\
\hline Blocks & 4 & 542.2406 & & & \\
Varieties & 7 & 793.9257 & 113.4180 & & $672.05^{* * *}$ \\
\hline $\mathrm{Y}_{1}$ & 1 & 752.7520 & & 0.35 & 6.65 \\
$\mathrm{Y}_{2}$ & 1 & 0.4420 & & 0.62 & 7.85 \\
$\mathrm{Y}_{3}$ & 1 & 3.0810 & & 157.93 & $13.7^{* * *}$ \\
$\mathrm{Y}_{4}$ & 1 & 18.7690 & & 0.46 & -1.7 \\
$\mathrm{Y}_{5}$ & 1 & 0.2890 & & 2.55 & -19.55 \\
$\mathrm{Y}_{6}$ & 1 & 12.7400 & & 0.94 & \\
$\mathrm{Y}_{7}$ & 1 & 5.8520 & & & \\
Residual & 28 & 348.3240 & 12.4401 & \\
\hline $\mathrm{R}\left(\mathrm{Y}_{1}\right)$ & 4 & 275.6050 & 68.9014 & & \\
$\mathrm{R}\left(\mathrm{Y}_{2}\right)$ & 4 & 5.0403 & 1.26007 & & \\
$\mathrm{R}\left(\mathrm{Y}_{3}\right)$ & 4 & 19.8226 & 4.95566 & & \\
$\mathrm{R}\left(\mathrm{Y}_{4}\right)$ & 4 & 0.4754 & 0.11884 & & \\
$\mathrm{R}\left(\mathrm{Y}_{5}\right)$ & 4 & 2.5204 & 0.63009 & & \\
$\mathrm{R}\left(\mathrm{Y}_{6}\right)$ & 4 & 19.9539 & 4.98847 & & \\
$\mathrm{R}\left(\mathrm{Y}_{7}\right)$ & 4 & 24.9059 & 6.22647 & & \\
\hline Total & 39 & $1,684.6119$ & & & \\
\hline $\mathrm{N}$ & 4 & & & \\
\hline
\end{tabular}

Note: *significance by $(0.01<p$-Value $\leq 0.05)$; **significance by $(p$-Value $\leq 0.01)$.

Table 12 - Analyses of variance without specific residue procedure application.

\begin{tabular}{lccccc}
\hline Sources of Variation & DF & \multicolumn{1}{c}{ SS } & MS & F Test & $\hat{Y}_{h}$ \\
\hline Blocks & 4 & 542.2406 & & & \\
Varieties & 7 & 793.9257 & 113.4180 & & $672.05 * *$ \\
$Y_{1}$ & 1 & 752.7520 & & 60.51 & 6.65 \\
$Y_{2}$ & 1 & 0.4422 & & 0.04 & 7.85 \\
$Y_{3}$ & 1 & 3.0811 & & 0.25 & 13.7 \\
$Y_{4}$ & 1 & 18.7690 & & 1.51 & -1.7 \\
$Y_{5}$ & 1 & 0.2890 & & 0.02 & -19.55 \\
$Y_{6}$ & 1 & 12.7401 & & 1.02 & 7.65 \\
$Y_{7}$ & 1 & 5.8522 & & 0.47 & \\
Residual & 28 & 348.3238 & 12.4401 & & \\
\hline Total & 39 & $1,684.6119$ & & & \\
\hline
\end{tabular}

Note: *significance by $(0.01<p$-Value $\leq 0.05)$; **significance by $(p$-Value $\leq 0.01)$.

The analysis of variance without the specific residue procedure was also obtained (Table 12) in order to be compared to the previous analysis (Table 11). Significant $F$ value was obtained for the $\mathrm{Y}_{1}$ contrast when calculated with MSResidual as denominator, with 28 degrees of freedom, evidencing that it significantly differed from zero. When the specific residue procedure was applied (Table 11), significant $F$ values were obtained for the $Y_{1}$ and $Y_{4}$ contrasts.

\section{Conclusion}

The use of the specific residue procedure is a valid and efficient alternative when heteroscedasticity is present, because it validates the applied tests and also allows a better understanding of the residual mean square nature. The MSResidual corresponds to the $\operatorname{MSR}\left(\mathrm{Y}_{\mathrm{h}}\right)$ arithmetic mean, although the values obtained for $\operatorname{MSR}\left(\mathrm{Y}_{\mathrm{h}}\right)$ can be different. In the presence of homoscedasticity the values obtained for $\operatorname{MSR}\left(\mathrm{Y}_{\mathrm{h}}\right)$ are very close to those obtained for MSResidual.

\section{References}

Box, G.E.P; Miller, M.E. 1958. A note on the generation of random normal deviates. Annals of Mathematics Statistics 29: 610-611.

Cochran, W.G. 1947. Some consequences when the assumptions for the analysis of variance are not satisfied. Biometrics 3: 2238. 
Cochran, W.G.; Cox, G.M. 1957. Experimental Designs. 2ed. John Wiley, New York, NY, USA.

Cochran, W.G.; Cox, G.M. 1971. Diseños Experimentales. Editorial Trillas, Ciudad de México, México.

Godoi, C.R.M. 1978. Um algoritmo eficiente para simulação de vetores com distribuição multinormal. Ciência e Cultura 20: 701-705.

Ferreira, L.E.P. 1978. A decomposição do resíduo em casos de heterocedasticidade nas análises de variância de ensaios em blocos casualizados. MSc Dissertation. Universidade de São Paulo, Piracicaba, SP, Brazil. (in Portuguese with summary in English).

Nogueira, I.R. 1978. Método geral para obtenção de tabelas de polinômios ortogonais. Revista da Agricultura 53: 269-279.

Nogueira, M.C.S. 1984. Resíduo específico para contraste de tratamentos no delineamento inteiramente casualizado. Dr. Thesis. Universidade de São Paulo, Piracicaba, SP, Brazil (in Portuguese with summary in English).

Nogueira, M.C.S.; Campos, H. 1985. Resíduo específico para contraste de tratamentos no delineamento inteiramente casualizado. Anais do Simpósio de Estatística Aplicada à Experimentação Agronômica 1. Fundação Cargill, Piracicaba, SP, Brazil.
Nogueira, M.C.S. 2004. Orthogonal contrasts: Definitions and concepts. Scientia Agricola 61: 118-124.

Nogueira, M.C.S. 2007. Experimentação agronômica I. Conceitos, planejamento e análise de dados. Editora MCSNogueira, Piracicaba, SP, Brazil.

Oliveira, W.; Nogueira, M.C.S. 2007. Aplicação do resíduo específico na análise de grupos de experimentos. Bragantia 66: 737-744.

Satterthwaite, F.E. 1941. Synthesis of variance. Psychometrika 6: 309-316.

Satterthwaite, F.E. 1946. An approximate distribution of estimates of variance components. Biometrics Bulletin 2: 110-114.

Steel, R.G.D.; Torrie, J.H. 1981. Principles and Procedures of Statistics. 2ed. McGraw-Hill, New York, NY, USA.

Received June 15, 2007

Accepted August 21, 2009 